\title{
Front Matter: Volume 7804
}

, "Front Matter: Volume 7804," Proc. SPIE 7804, Developments in X-Ray Tomography VII, 780401 (22 October 2010); doi: 10.1117/12.877483

SPIE Event: SPIE Optical Engineering + Applications, 2010, San Diego, California, SPIE. United States 


\section{PROCEEDINGS OF SPIE}

\section{Developments in X-Ray Tomography VII}

\section{Stuart R. Stock}

Editor

2-5 August 2010

San Diego, California, United States

Sponsored and Published by

SPIE 
The papers included in this volume were part of the technical conference cited on the cover and title page. Papers were selected and subject to review by the editors and conference program committee. Some conference presentations may not be available for publication. The papers published in these proceedings reflect the work and thoughts of the authors and are published herein as submitted. The publisher is not responsible for the validity of the information or for any outcomes resulting from reliance thereon.

Please use the following format to cite material from this book:

Author(s), "Title of Paper," in Developments in X-Ray Tomography VII, edited by Stuart R. Stock, Proceedings of SPIE Vol. 7804 (SPIE, Bellingham, WA, 2010) Article CID Number.

ISSN 0277-786X

ISBN 9780819483003

Published by

SPIE

P.O. Box 10, Bellingham, Washington 98227-0010 USA

Telephone +1 3606763290 (Pacific Time) · Fax +1 3606471445

SPIE.org

Copyright (c) 2010, Society of Photo-Optical Instrumentation Engineers

Copying of material in this book for internal or personal use, or for the internal or personal use of specific clients, beyond the fair use provisions granted by the U.S. Copyright Law is authorized by SPIE subject to payment of copying fees. The Transactional Reporting Service base fee for this volume is $\$ 18.00$ per article (or portion thereof), which should be paid directly to the Copyright Clearance Center (CCC), 222 Rosewood Drive, Danvers, MA 01923. Payment may also be made electronically through CCC Online at copyright.com. Other copying for republication, resale, advertising or promotion, or any form of systematic or multiple reproduction of any material in this book is prohibited except with permission in writing from the publisher. The CCC fee code is 0277-786X/10/\$18.00.

Printed in the United States of America.

Publication of record for individual papers is online in the SPIE Digital Library.

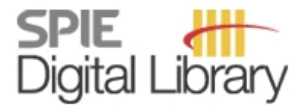

SPIEDigitalLibrary.org

Paper Numbering: Proceedings of SPIE follow an e-First publication model, with papers published first online and then in print and on CD-ROM. Papers are published as they are submitted and meet publication criteria. A unique, consistent, permanent citation identifier (CID) number is assigned to each article at the time of the first publication. Utilization of CIDs allows articles to be fully citable as soon they are published online, and connects the same identifier to all online, print, and electronic versions of the publication. SPIE uses a six-digit CID article numbering system in which:

- The first four digits correspond to the SPIE volume number.

- The last two digits indicate publication order within the volume using a Base 36 numbering system employing both numerals and letters. These two-number sets start with 00, 01, 02, 03, 04 , $05,06,07,08,09,0 A, 0 B \ldots$. OZ, followed by 10-1Z, 20-2Z, etc.

The CID number appears on each page of the manuscript. The complete citation is used on the first page, and an abbreviated version on subsequent pages. Numbers in the index correspond to the last two digits of the six-digit CID number. 


\section{Contents}

ix Conference Committee

xi Introduction

xiii Competition: Most Artistic Tomography-based Image [7804-19]

S. R. Stock, Northwestern Univ. (United States)

OPENING REMARKS

780402 Trends in micro- and nanoComputed Tomography 2008-2010 [7804-01]

S. R. Stock, Northwestern Univ. (United States)

\section{SESSION 1 PHASE CONTRAST}

780403 High-resolution x-ray phase tomography (Invited Paper) [7804-02]

A. G. Peele, La Trobe Univ. (Australia) and Australian Research Council Ctr. of Excellence for Coherent X-ray Science (Australia); C. D. L. Thomas, J. G. Clement, The University of Melbourne (Australia); B. D. Arhatari, K. M. Hannah, C. Doshi, C. T. Putkunz, La Trobe Univ. (Australia) and Australian Research Council Ctr. of Excellence for Coherent X-ray Science (Australia); J. N. Clark, La Trobe Univ. (Australia), Australian Research Council Ctr. of Excellence for Coherent X-ray Science (Australia), and Univ. College London (United Kingdom)

780404 An examination of phase retrieval algorithms as applied to phase contrast tomography using laboratory sources (Invited Paper) [7804-03]

R. S. Bradley, A. McNeil, P. J. Withers, The Univ. of Manchester (United Kingdom)

780405 Four-dimensional x-ray phase tomography with Talbot interferometer and white synchrotron light [7804-04]

A. Momose, W. Yashiro, S. Harasse, H. Kuwabara, K. Kawabata, The Univ. of Tokyo (Japan) 
780406 Recent developments in x-ray Talbot interferometry at ESRF-ID19 [7804-05]

T. Weitkamp, European Synchrotron Radiation Facility (France) and Synchrotron Soleil (France); I. Zanette, European Synchrotron Radiation Facility (France); C. David, Paul Scherrer Institut (Switzerland); J. Baruchel, European Synchrotron Radiation Facility (France); M. Bech, Technische Univ. München (Germany); P. Bernard, European Synchrotron Radiation Facility (France); H. Deyhle, Univ. Basel (Switzerland); T. Donath, Paul Scherrer Institut (Switzerland); J. Kenntner, Karlsruher Institut für Technologie (Germany); S. Lang, Univ. Basel (Switzerland); J. Mohr, Karlsruher Institut für Technologie (Germany); B. Müller, Univ. Basel (Switzerland); F. Pfeiffer, Technische Univ. München (Germany); E. Reznikova, Karlsruher Institut für Technologie (Germany); S. Rutishauser, Paul Scherrer Institut (Switzerland); G. Schulz, Univ. Basel (Switzerland); A. Tapfer, Technische Univ. München (Germany); J.-P. Valade, European Synchrotron Radiation Facility (France)

$780407 \quad X$-ray grating interferometer for imaging at a second-generation synchrotron radiation source [7804-06]

J. Herzen, GKSS-Forschungszentrum Geesthacht (Germany) and Technische Univ. München (Germany); F. Beckmann, GKSS-Forschungszentrum Geesthacht (Germany); T. Donath, Dectris AG (Switzerland) and Paul Scherrer Institut (Switzerland); M. Ogurreck, GKSS-Forschungszentrum Geesthacht (Germany); C. David, Paul Scherrer Institut (Switzerland); F. Pfeiffer, Technische Univ. München (Germany); J. Mohr, E. Reznikova, Karlsruher Institut für Technologie (Germany); S. Riekehr, A. Haibel, GKSS-Forschungszentrum Geesthacht (Germany); G. Schulz, B. Müller, Univ. Basel (Switzerland); A. Schreyer, GKSS-Forschungszentrum Geesthacht (Germany)

780408 Front- and backside structuring of gratings for phase contrast imaging with $\mathrm{x}$-ray tubes [7804-07]

J. Kenntner, T. Grund, B. Matthis, M. Boerner, J. Mohr, T. Scherer, Karlsruher Institut für Technologie (Germany); M. Walter, Microworks GmbH (Germany); M. Willner, A. Tapfer, M. Bech, F. Pfeiffer, Technische Univ. München (Germany)

\section{SESSION 2 SYNCHROTRON TOMOGRAPHY}

780409 Recent developments in computed tomography at GSECARS (Invited Paper) [7804-08] M. L. Rivers, D. T. Citron, Y. Wang, The Univ. of Chicago (United States)

7804 OB Micro- and nano-tomography at the GKSS Imaging Beamline at PETRA III [7804-10] A. Haibel, M. Ogurreck, F. Beckmann, T. Dose, F. Wilde, J. Herzen, M. Müller, A. Schreyer, GKSS-Forschungszentrum Geesthacht (Germany); V. Nazmov, M. Simon, A. Last, J. Mohr, Karlsruher Institut für Technologie (Germany)

\section{SESSION 3 BIOLOGICAL SAMPLES}

7804 OD Morphology of urethral tissues (Invited Paper) [7804-12]

B. Müller, G. Schulz, Univ. Basel (Switzerland); J. Herzen, GKSS-Forschungszentrum Geesthacht (Germany); S. Mushkolaj, T. Bormann, Univ. Basel (Switzerland); F. Beckmann, GKSS-Forschungszentrum Geesthacht (Germany); K. Püschel, Univ. Hospital Hamburg-Eppendorf (Germany) 
$7804 \mathrm{OE}$ Ex vivo and in vitro synchrotron-based micro-imaging of biocompatible materials applied in dental surgery [7804-13]

A. Rack, European Synchrotron Radiation Facility (France); M. Stiller, K. Nelson, C. Knabe, T. Rack, Charité Universitätsmedizin Berlin (Germany); S. Zabler, Technische Univ. Berlin (Germany); O. Dalügge, Charité Universitätsmedizin Berlin (Germany); H. Riesemeier, Bundesanstalt für Materialforschung und -prüfung (Germany); A. Cecilia, Karlsruher Institut für Technologie (Germany); J. Goebbels, Bundesanstalt für Materialforschung und -prüfung (Germany)

7804 OF Evaluating the microstructure of human brain tissues using synchrotron radiation-based micro-computed tomography [7804-14]

G. Schulz, Univ. of Basel (Switzerland); A. Morel, Univ. Hospital Zurich (Switzerland); M. S. Imholz, H. Deyhle, Univ. of Basel (Switzerland); T. Weitkamp, I. Zanette, European Synchrotron Radiation Facility (France); F. Pfeiffer, Technische Univ. München (Germany); C. David, Paul Scherrer Institut (Switzerland); M. Müller-Gerbl, B. Müller, Univ. of Basel (Switzerland)

\section{SESSION 4 TUBE-BASED TOMOGRAPHY}

$7804 \mathrm{OH} \quad$ Overview of multisource CT systems and methods (Invited Paper) [7804-16] J. Zhao, Y. LU, T. Zhuang, Shanghai Jiao Tong Univ. (China); G. Wang, Virginia Polytechnic Institute and State Univ. (United States)

7804 Ol Quantitative x-ray microtomography with a conventional source (Invited Paper) [7804-17] G. Davis, A. Evershed, J. Elliott, D. Mills, Queen Mary, Univ. of London (United Kingdom) and London School of Medicine and Dentistry (United Kingdom)

7804 0J An auto-focus method for generating sharp 3D tomographic images [7804-18] A. M. Kingston, A. Sakellariou, A. P. Sheppard, T. K. Varslot, S. J. Latham, The Australian National Univ. (Australia)

\section{SESSION 5 ANALYSIS}

7804 OL Deciphering complex, functional structures with synchrotron-based absorption and phase contrast tomographic microscopy (Invited Paper) [7804-20]

M. Stampanoni, Paul Scherrer Institut (Switzerland) and ETH Zurich (Switzerland); J. Reichold, ETH Zurich (Switzerland); B. Weber, Univ. Zürich (Switzerland); D. Haberthür, J. Schittny, Univ. Bern (Switzerland); J. Eller, F. N. Büchi, F. Marone, Paul Scherrer Institut (Switzerland)

7804 OM Optimizing synchrotron microCT for high-throughput phenotyping of zebrafish (Invited Paper) [7804-21]

P. J. La Rivière, The Univ. of Chicago (United States); D. Clark, Penn State College of Medicine (United States); A. Rojek, P. Vargas, The Univ. of Chicago (United States); X. Xiao, F. DeCarlo, Argonne National Lab. (United States); G. Kindlmann, The Univ. of Chicago (United States); K. Cheng, Penn State College of Medicine (United States)

7804 ON Data-constrained microstructure modeling with multi-spectrum x-ray CT (Invited Paper) [7804-22]

Y. S. Yang, A. M. Tulloh, T. Muster, A. Trinchi, S. C. Mayo, S. W. Wilkins, Commonwealth Scientific and Industrial Research Organisation (Australia) 
780400 Precise 3D dimensional metrology using high-resolution $\mathrm{x}$-ray computed tomography $(\mu \mathrm{CT})$ [7804-23]

O. Brunke, GE Sensing \& Inspection Technologies GmbH (Germany); J. Santillan, GE Sensing \& Inspection Technologies Inc. (United States); A. Suppes, GE Sensing \& Inspection Technologies GmbH (Germany)

7804 OP Tomographic image analysis and processing to simulate micro-petrophysical experiments [7804-24]

A. Sakellariou, A. M. Kingston, T. K. Varslot, A. P. Sheppard, S. J. Latham, The Australian National Univ. (Australia); R. M. Sok, Digital Core Labs. Pty Ltd. (Australia); C. H. Arns, The Univ. of New South Wales (Australia); T. J. Senden, M. A. Knackstedt, The Australian National Univ. (Australia)

SESSION 6

NANOTOMOGRAPHY

$78040 Q \quad$ New type of $x$-ray source for lensless laboratory nano-CT with 50 -nm resolution [7804-25] A. Sasov, B. Pauwels, P. Bruyndonckx, SkyScan N.V. (Belgium)

7804 OR High-resolution 3D imaging of polymerized photonic crystals by lab-based $x$-ray

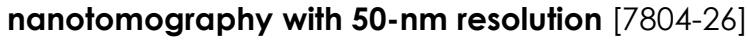

L. Yin, Y.-C. Chen, Univ. of Illinois at Urbana-Champaign (United States); J. Gelb, Xradia, Inc. (United States); D. M. Stevenson, P. A. Braun, Univ. of Illinois at Urbana-Champaign (United States)

7804 OS X-ray nanotomography in a SEM [7804-27]

B. Pauwels, X. Liu, A. Sasov, SkyScan N.V. (Belgium)

7804 OU Key components for artifact-free micro-CT and nano-CT instruments [7804-29]

A. Sasov, B. Pauwels, X. Liu, P. Bruyndonckx, SkyScan N.V. (Belgium)

\section{SESSION 7 RECONSTRUCTION}

$78040 V \quad$ Recent progress in local reconstruction (Invited Paper) [7804-30]

H. Yu, Wake Forest Univ. Health Sciences (United States) and Virginia Polytechnic Institute and State Univ. (United States); Q. Xu, X. Mou, Xi'an Jiaotong Univ. (China); G. Wang, Wake Forest Univ. Health Sciences (United States) and Virginia Polytechnic Institute and State Univ. (United States)

7804 0X Three-dimensional reconstruction with x-ray shape-from-silhovette [7804-32] E. Simioni, F. Ratti, Istituto di Fotonica e Nanotecnologie, CNR (Italy) and Univ. degli Studi di Padova (Italy); I. Calliari, Univ. degli Studi di Padova (Italy); L. Poletto, Istituto di Fotonica e Nanotecnologie, CNR (Italy) and Univ. degli Studi di Padova (Italy)

$78040 Z$ Regularization methods for inverse problems in x-ray tomography [7804-34] V. Titarenko, R. Bradley, C. Martin, P. J. Withers, The Univ. of Manchester (United Kingdom); S. Titarenko, Lomonosov Moscow State Univ. (Russian Federation) 
780410 Fast reconstruction algorithm dealing with tomography artifacts [7804-35]

F. Marone, Paul Scherrer Institut (Switzerland); B. Münch, EMPA Materials Science and Technology (Switzerland); M. Stampanoni, Paul Scherrer Institut (Switzerland) and ETH Zürich (Switzerland)

$780411 \quad$ X-ray phase laminography with Talbot interferometer [7804-36]

S. Harasse, N. Hirayama, W. Yashiro, A. Momose, The Univ. of Tokyo (Japan)

SESSION 8 NONCONVENTIONAL ALTERNATIVES

780412 Development of a CT scanner based on the Medipix family of detectors (Invited Paper) [7804-37]

P. J. Bones, Univ. of Canterbury (New Zealand); A. P. H. Butler, J. P. Ronaldson, Univ. of Otago (New Zealand); A. M. T. Opie, Univ. of Canterbury (New Zealand)

780413 Fast high-resolution micro-CT with exact reconstruction methods [7804-38]

T. Varslot, A. Kingston, A. Sheppard, A. Sakellariou, The Australian National Univ. (Australia)

\section{SESSION $9 \quad$ NATURAL MATERIALS}

$780416 \quad X$-ray tomography verification for determining phase proportions in volcanic rocks [7804-41]

D. M. Stevenson, L. Yin, Univ. of Illinois at Urbana-Champaign (United States) and Beckman Institute for Advanced Science and Technology (United States); M. A. Stewart, Univ. of Illinois at Urbana-Champaign (United States) and School of Earth, Society, and Environment (United States)

780417 Evaluating tooth restorations: micro-computed tomography in practical training for students in dentistry [7804-42]

H. Deyhle, Univ. Basel, Univ. Hospital (Switzerland) and Univ. Basel (Switzerland); F. Schmidli, G. Krastl, Univ. Basel (Switzerland); B. Müller, Univ. Basel, Univ. Hospital (Switzerland) and Univ. Basel (Switzerland)

\section{SESSION 10 FLUORESCENCE}

780419 Reconstruction algorithms for laboratory microCT/microXRF system [7804-44]

X. Liu, P. Bruyndonckx, A. Sasov, SkyScan N.V. (Belgium)

7804 1A Progress in development of a laboratory microXRF-microCT system [7804-45] P. Bruyndonckx, A. Sasov, X. Liu, J. Van Geert, SkyScan N.V. (Belgium)

7804 1B X-ray fluorescence tomography using imaging detectors [7804-46] L.-J. Meng, G. Fu, N. Li, Univ. of Illinois at Urbana-Champaign (United States); M. Newville, P. Eng, Consortium for Advanced Radiation Sources, The Univ. of Chicago (United States);

P. La Rivière, The Univ. of Chicago (United States) 
7804 IF Computed tomography to quantify tooth abrasion [7804-50]

L. Kofmehl, G. Schulz, H. Deyhle, A. Filippi, Univ. Basel (Switzerland); G. Hotz, Natural History Museum Basel (Switzerland) and Univ. Basel (Switzerland); D. Berndt-Dagassan, S. Kramis, Univ. Basel (Switzerland); F. Beckmann, GKSS-Forschungszentrum Geesthacht (Germany); B. Müller, Univ. of Basel (Switzerland)

7804 IG The microstructure of mandibular bone grafts and three-dimensional cell clusters [7804-51] S. Gürel, C. Unold, H. Deyhle, G. Schulz, S. Kühl, Univ. Basel (Switzerland); B. Saldamli, J. Tübel, R. Burgkart, Technische Univ. München (Germany); F. Beckmann, GKSS-Forschungszentrum Geesthacht (Germany); B. Müller, Univ. Basel (Switzerland)

$7804 \mathrm{1H}$ The morphology of amputated human teeth and its relation to mechanical properties after restoration treatment [7804-52]

J. Gugger, G. Krastl, Univ. Basel (Switzerland); M. Huser, Image Lab GmbH (Switzerland);

H. Deyhle, B. Müller, Univ. Basel (Switzerland)

$780411 \quad$ Statistical interior tomography [7804-53]

Q. XU, Xi'an Jiaotong Univ. (China); H. Yu, Wake Forest Univ. Health Sciences (United States); $X$. Mou, Xi'an Jiaotong Univ. (China); G. Wang, Wake Forest Univ. Health Sciences (United States) and Virginia Polytechnic Institute and State Univ. (United States)

7804 1J Scanning multiple samples simultaneously in tube-based microCT systems [7804-54] S. R. Stock, N. M. Rajamannan, Northwestern Univ. (United States); T. C. Spelsberg, S. Malayannan, Mayo Clinic (United States); R. Riaz, M. Polavarapu, E. L. Hsu, W. K. Hsu, Y. Chen, M. Zhang, Northwestern Univ. (United States)

$78041 \mathrm{M}$ Determination of strain fields in porous shape memory alloys using micro-computed tomography [7804-58]

T. Bormann, Univ. Basel (Switzerland) and Univ. of Applied Sciences, Northwestern Switzerland (Switzerland); S. Friess, Gloor Instruments AG (Switzerland); M. de Wild, R. Schumacher, Univ. of Applied Sciences, Northwestern Switzerland (Switzerland); G. Schulz, B. Müller, Univ. Basel (Switzerland)

780410 Tomographic imaging of coherent $x$-ray scatter momentum transfer distribution using spectral $x$-ray detection and polycapillary optic [7804-60]

D. R. Eaker, S. M. Jorgensen, Mayo Clinic (United States); A. P. H. Butler, Univ. of Canterbury (New Zealand) and Univ. of Otago Medical School (New Zealand); E. L. Ritman, Mayo Clinic (United States)

$78041 Q \quad$ Imaging fossilised spiders in amber using lab-based phase contrast $x$-ray tomography [7804-62]

A. McNeil, R. S. Bradley, P. J. Withers, D. Penney, The Univ. of Manchester (United Kingdom)

Author Index 


\title{
Conference Committee
}

\author{
Program Track Chair
}

Carolyn A. MacDonald, University at Albany (United States)

Conference Chair

Stuart R. Stock, Northwestern University (United States)

Program Committee

Felix Beckmann, GKSS-Forschungszentrum Geesthacht (Germany)

Graham R. Davis, Queen Mary University of London (United Kingdom)

Bert Müller, Basel University Hospital (Switzerland)

Erik L. Ritman, Mayo Clinic College of Medicine (United States)

Mark L. Rivers, The University of Chicago (United States)

Ge Wang, Virginia Polytechnic Institute and State University (United States)

Stephen W. Wilkins, Commonwealth Scientific and Industrial Research Organisation (Australia)

Session Chairs

1 Phase Contrast

Stuart R. Stock, Northwestern University (United States)

2 Synchrotron Tomography

Bert Müller, University Basel (Switzerland)

3 Biological Samples

Stephen W. Wilkins, Commonwealth Scientific and Industrial Research Organisation (Australia)

4 Tube-based Tomography

Erik L. Ritman, Mayo Clinic College of Medicine (United States)

$5 \quad$ Analysis

Mark L. Rivers, The University of Chicago (United States)

6 Nanotomography

Graham R. Davis, Queen Mary, University of London (United Kingdom) 
$7 \quad$ Reconstruction

Ge Wang, Virginia Polytechnic Institute and State University (United States)

8 Nonconventional Alternatives

Felix Beckmann, GKSS-Forschungszentrum Geesthacht (Germany)

9 Natural Materials

Stuart R. Stock, Northwestern University (United States)

10 Fluorescence

Stuart R. Stock, Northwestern University (United States)

11 Session 11

Stuart R. Stock, Northwestern University (United States) 


\section{Introduction}

The seventh conference in this series was marked by a slight change in format with Wednesday afternoon consisting of a plenary session joint between the various $x$-ray, gamma-ray and particle technology conferences. These four talks included one titled "4D X-ray Characterization of Metal Structures" by Dorte Juul Jensen of Ris $\varnothing$ National Laboratory (Denmark). This approach reconstructs polycrystalline specimens in a different fashion from most studies in this volume.

The diversity of applications underlined the mature interdisciplinary scope of the conference. Established groups continued the trend of more detailed and sophisticated analyses than in previous meeting, and new contributors (both early career and senior investigators) brought fresh ideas to the meeting. Papers describing advances in instrumentation and in reconstruction algorithms were met with great enthusiasm by the attendees.

I would like to thank the authors for their excellent contributions and the program committee for their very important help. Last, but not least, the SPIE staff provided exemplary support with the program development, the meeting itself and the proceedings.

Stuart R. Stock 


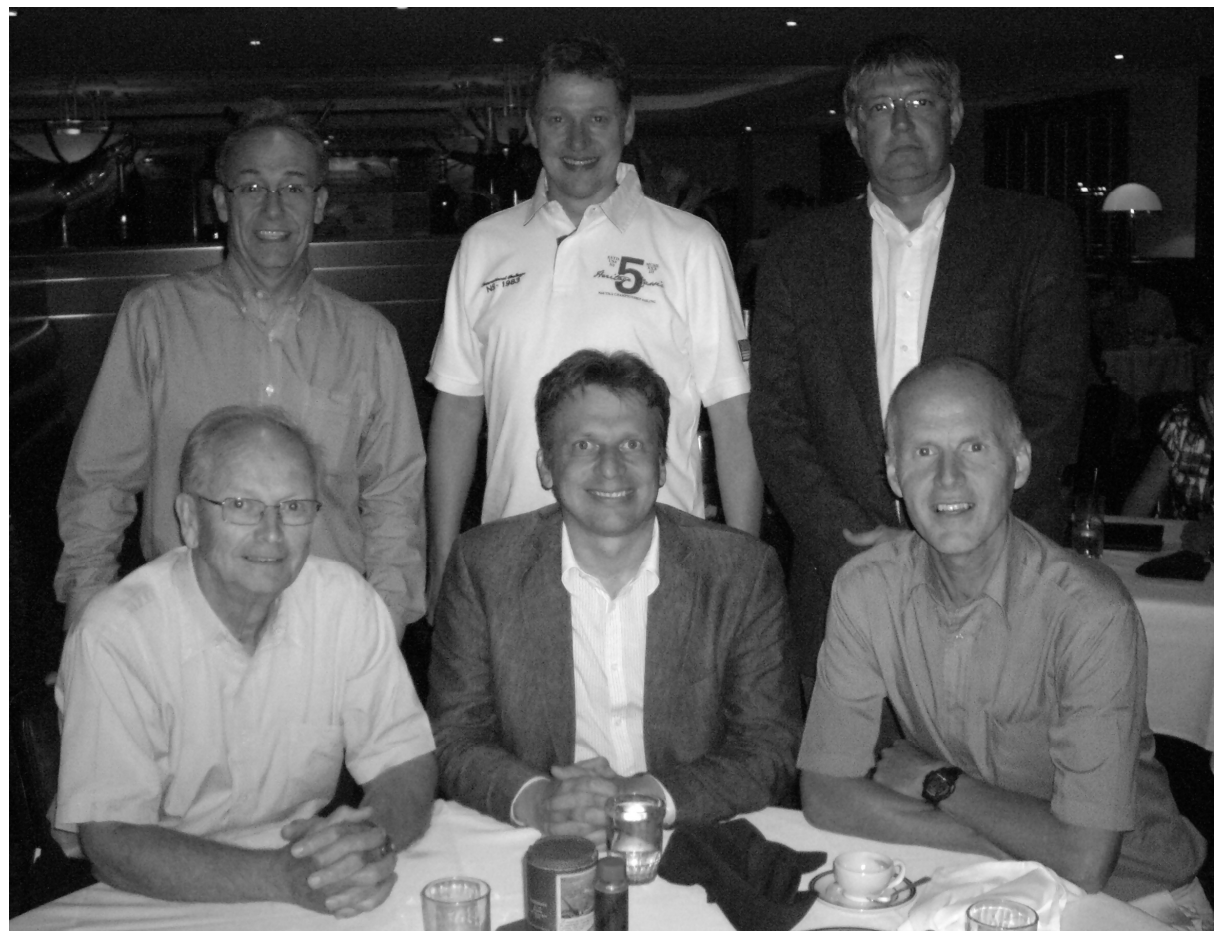

The program committee after their mid-conference planning meeting. From the left, bottom row: Erik Ritman, Bert Müller, Graham Davis; †op row: Mark Rivers, Felix Beckmann, Stuart Stock.

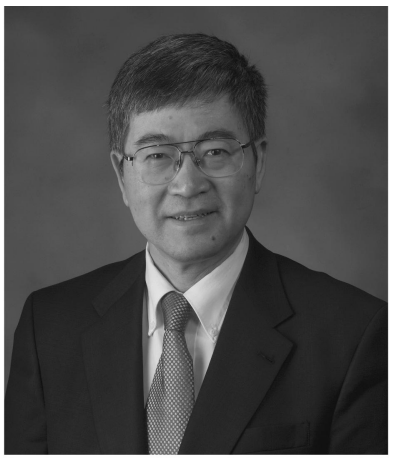

Members not in the group photo:

Ge Wang (top), Steve Wilkins (bottom).

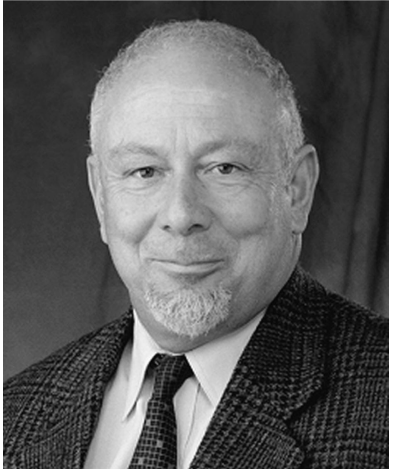




\title{
Competition: Most Artistic Tomography-based Image
}

\author{
S. R. Stock ${ }^{1}$, et al. \\ Department of Molecular Pharmacology and Biological Chemistry, Feinberg School of \\ Medicine, Northwestern University, 303 E. Chicago Ave., Chicago, IL USA
}

\begin{abstract}
Each image submitted for the competition is presented briefly. Images derived from tomography data and from the studies presented in Developments in X-ray Tomography VII are eligible. The sole criterion for the contest is artistic impression. One image per presentation (oral or poster) will be accepted in the format of a powerpoint slide. No animations allowed. Information on the image (title, authors and their affiliations) should follow on a second slide. Each image will be posted at the poster session and again in an oral session; winners will be announced during the oral sessions on the day following the second presentation.
\end{abstract}

Keywords: Tomography, artistic, image, x-ray

The first "Most Artistic Tomography-based Image" competition contained ten entries. The rules were: One submission was allowed per abstract presented at the Conference for which this is the proceedings. Each submission must be an x-ray tomography-based image (radiograph, slice, 3D rendering, sonogram. no animation). Each submission must not have been published previously.

The ten entries were displayed first at the poster session, Monday evening before the oral sessions began on Tuesday. The entries were again presented at the end of Tuesday's oral sessions. All of the entries (descriptions and author information first; image second) follow below (grayscale in the hard copy and color in the on-line versions of the proceedings). Immediately following the second presentation, the assembled attendees voted. The winners were announced at the end of the oral presentations on Wednesday. Three images were the attendees' favorites; these appear first and are labeled with ribbons. It is interesting that all entries received significant support, demonstrating the range of artistic preferences of the voters and entrants. The ordering among the winners and among the other entries is random.

\footnotetext{
1's-stock@northwestern.edu
} 


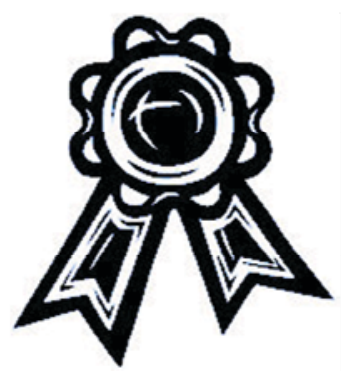

\section{Mosquito}

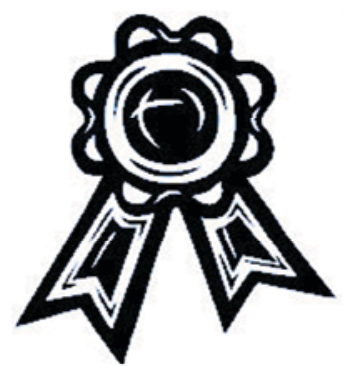

A. Rack*, T. Weitkamp*, A. Cecilia^, D. Wegrzynek", E. Chinea-Cano", P. Wobrauschek", Ch. Strelin

*European Synchrotron Radiation Facility, Grenoble, France ^Karlsruhe Institute of Technology - ANKA, Karlsruhe, Germany "International Atomic Energy Agency, Vienna, Austria Technische Universităt Wien, Vienna, Austria

Volume rendering showing the head of a malaria transmitting mosquito (genus Anopheles). Phase-sensitive microtomography recorded at the TopoTomo beamline of the ANKA light source (Germany) with a filtered white beam. Phase-retrieval performed via the ANKAphase software.

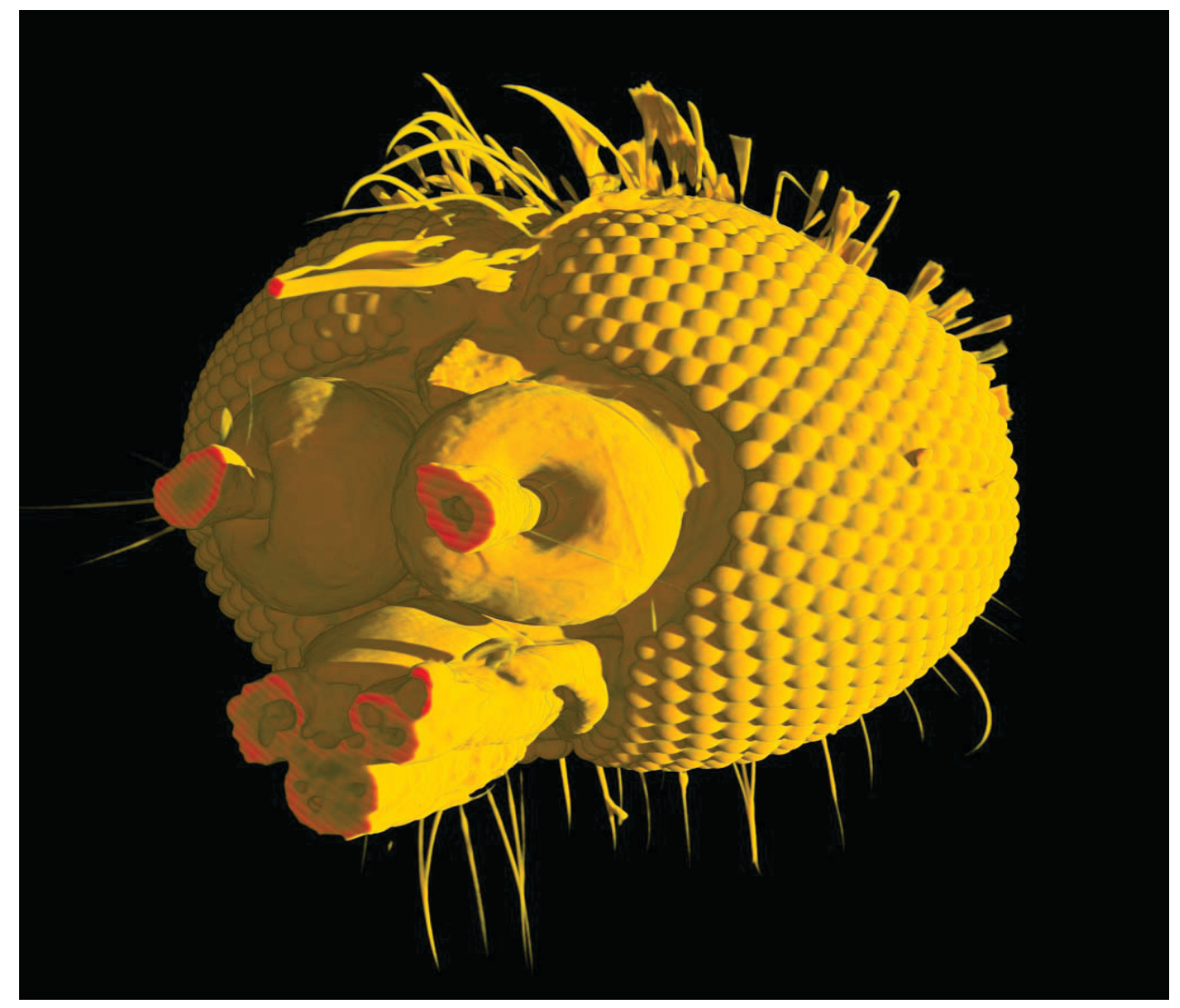




\section{The one that didn't get away!}

\section{Graham R Davis and David Mills}

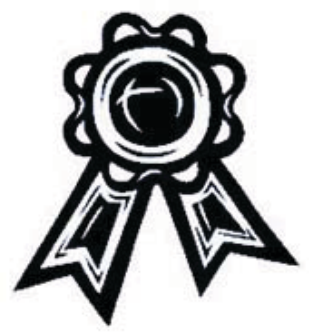

\section{Queen Mary University of London}

A partially developed gall wasp inside an intact oak gall; scanned on the MuCat 2 scanner and rendered with

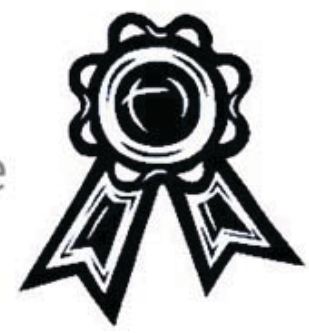

Drishti.

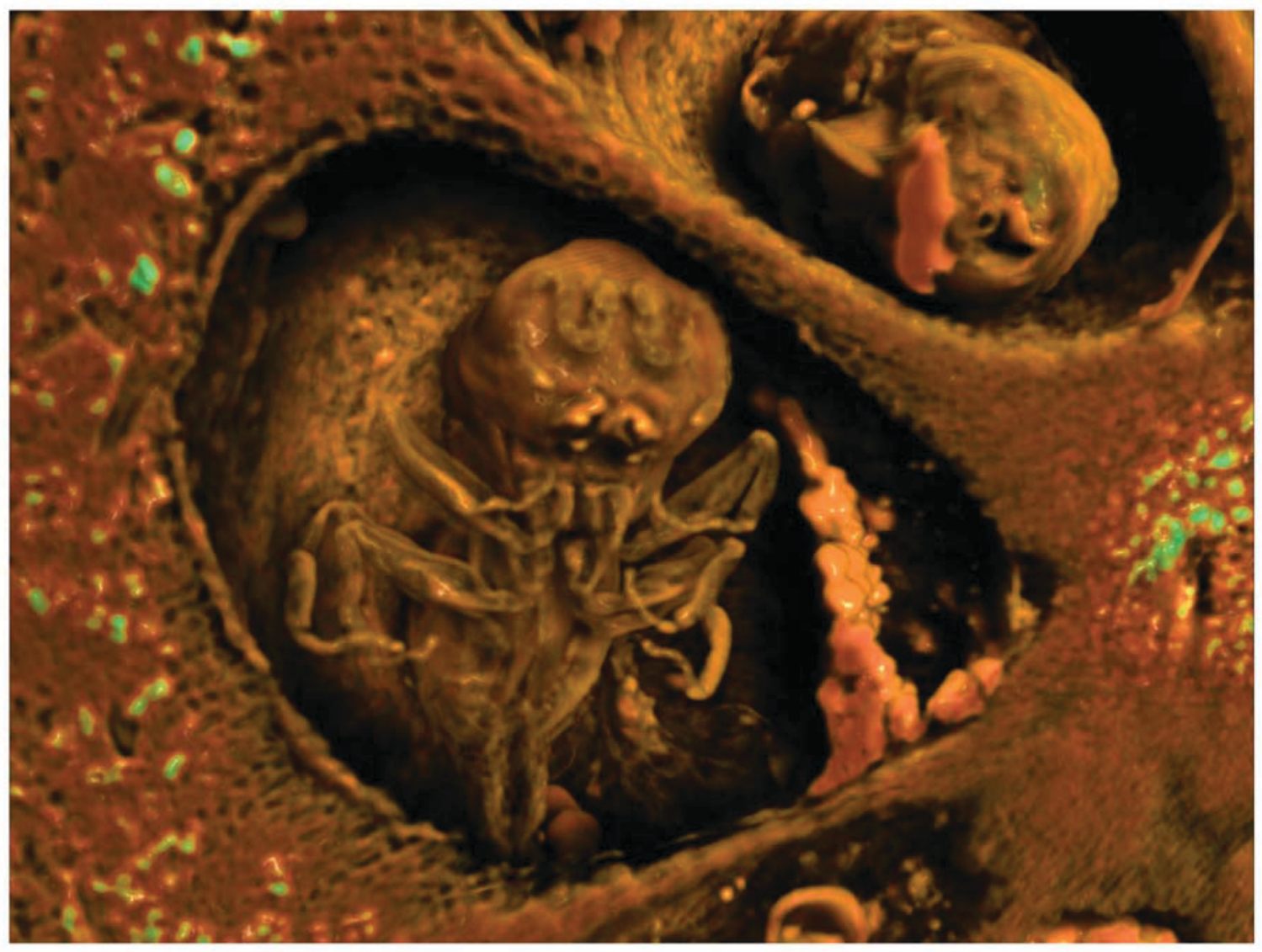




\section{Grating interferometry of a human cerebellum (c)

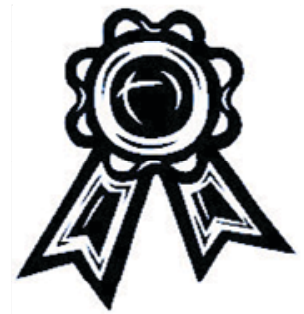 University of Basel, Basel, Switzerland}

The 3D rendering shows grating based phase contrast results of a part of a human cerebellum measured at ID19, ESRF, France. Beside the blood vessels one can differentiate between white (orange) and grey matter which can be divided into stratum moleculare (blue) and stratum granulosum (yellow, green). Furthermore, the golden image below shows a 3D visualization of individual Purkinje cells what was arranged without the application of any staining agents.

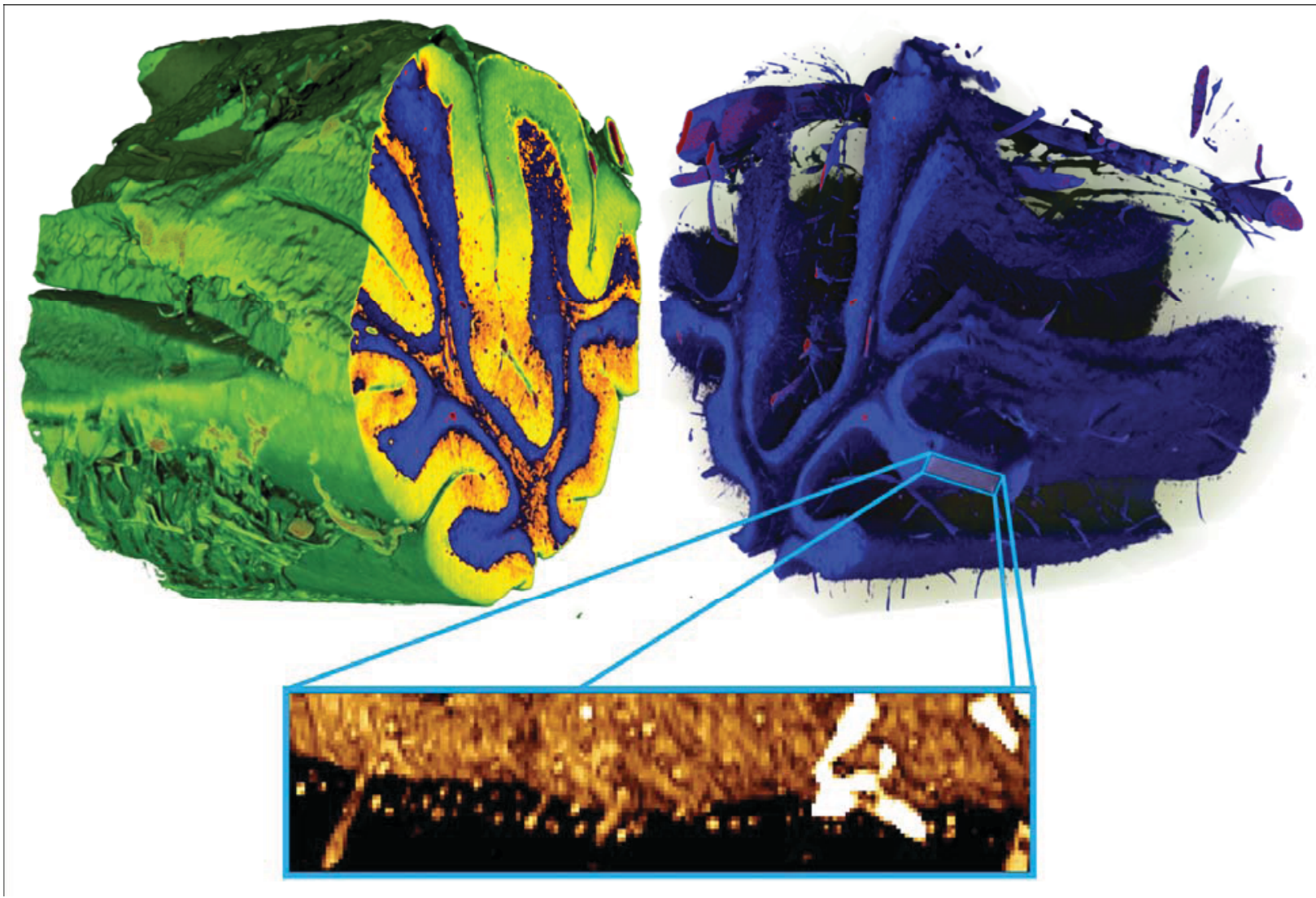




\title{
DROSOPHILA MELANOGASTER
}

\author{
Luca Poletto \\ National Council for Research - Institute for Photonics and \\ Nanotechnologies, Padova, Italy
}

Tomography of a Drosophila Melanogaster: external view. Recorded with a tube-based microCT system, $25 \mathrm{kV}, 800$ projections, 10 $\mu \mathrm{m}$ resolving element.

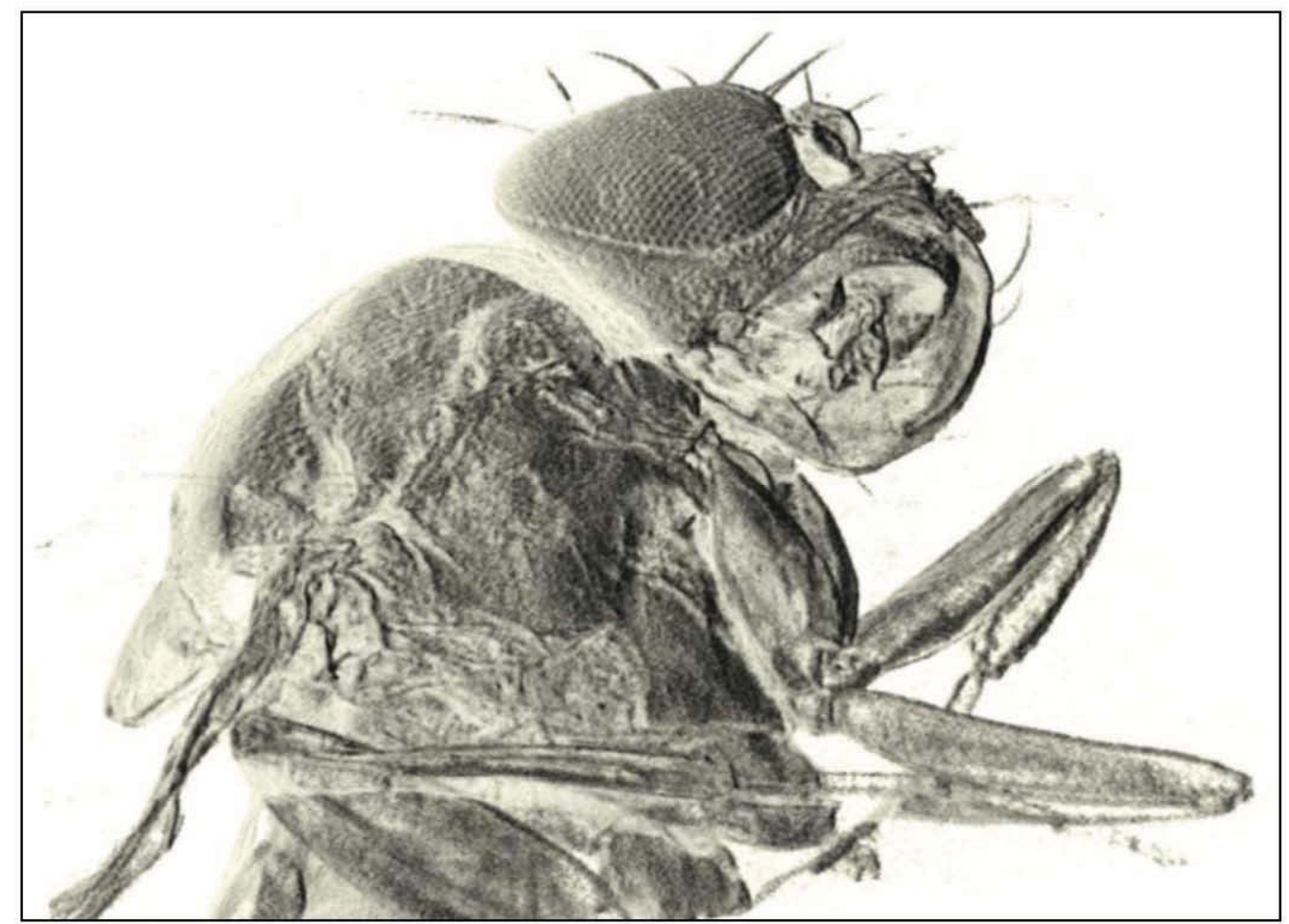




\section{Bone}

K. M Hannah ${ }^{1,2}$, C. D. Thomas ${ }^{3}$, J. G. Clement", F. De Carlo4, A. G. Peele ${ }^{1,2}$

1. Australan Research Coundl Centre of Exrellence for Coherent $X$-ray Sclence

2. Department of Physics, La Trobe University, Victoria 3096, Australia

3. Mebrowe Dental School, The University of Meboume, Victoria 301a, Austroting

4. Aduanced Photon Source, Argonne Notland Labonatory Arganne, Iinols 60439, USA

\section{Description}

A 3D rendered image of a section of human femur. Visible are the Haversian canals (large features) and surrounding osteocyte lacunae (small features). Data obtained at 2BM, Advanced Photon Source, Image created using Amlra V4.1.

\section{Acknowledgements}

The authors acknowledge the support of the Australian Research Coundil through the Centre of Excellence for Coherent $X$-ray Science, The authors also acknowledge the Australian Synchrotron Research Progran, which is funded by the Commonwealth of Australia under the Majer National Research Facilities Program. Use of the Advanced Photon Source was supported by the U.S. DOE, Basic. Energy Sciences, Ofice of Science under Contract Ho. W-31-109-Eng-38. We are grateful to the mortuary staff and the staff of the Donor Tissue Bank of the Victorian Instritute of Forensic Medicine for their assistance in the collection of the series of bone specimens from which this sample was taken, and particularty grateful to the next-of-kin of the donor for permission to remowe bone fior research purposes.

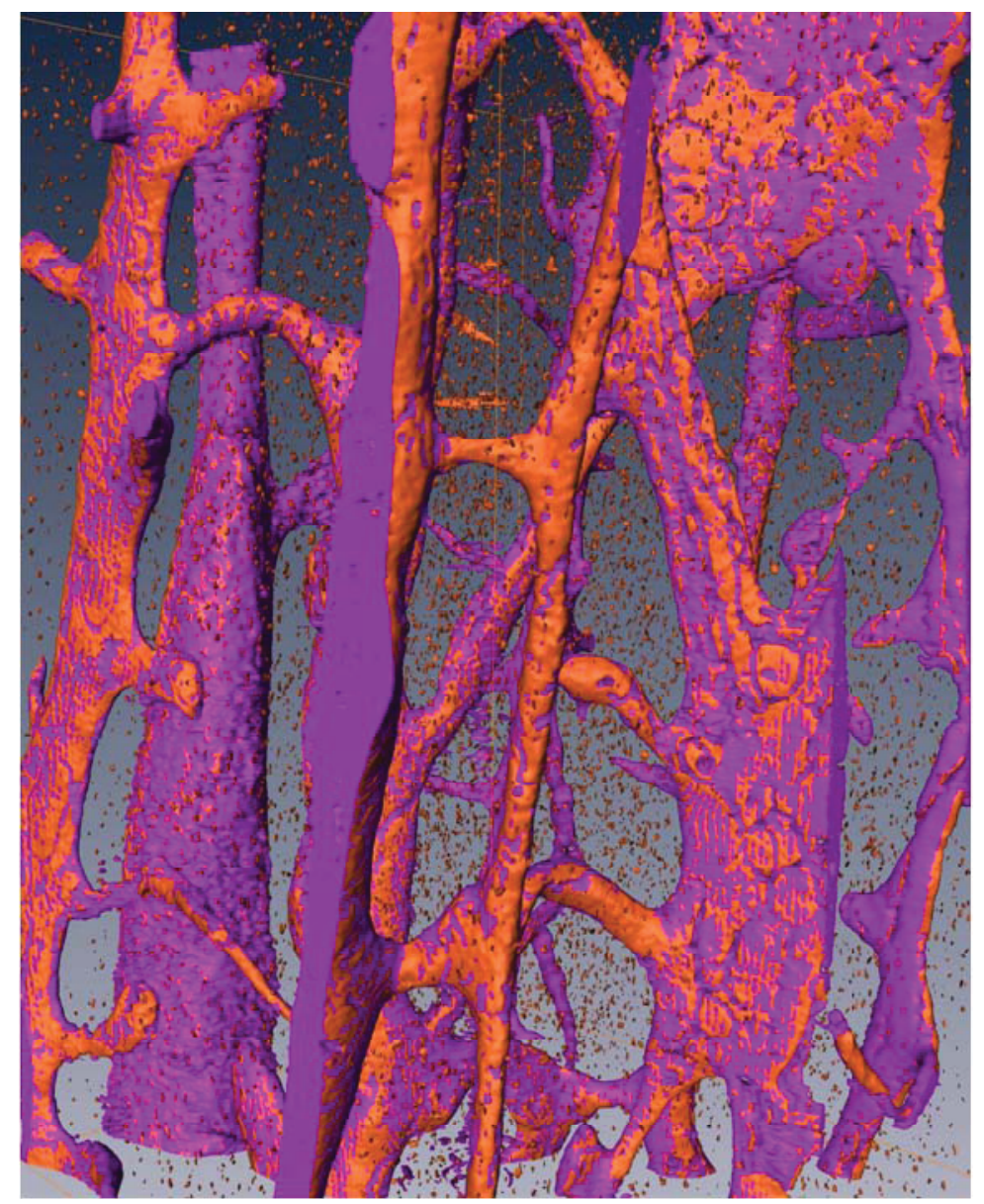




\title{
spierock
}

\author{
D.M. Stevenson* \\ *Beckman Institute for Advanced Science \& Technology, \\ University of Illinois at Urbana-Champaign, USA
}

Three dimensional surface rendering from segmented $x$-ray tomography data of Igneous rock, obtalned on tube-based microcT system. The SPIE logo was used as a volume mask across the entire dataset to create the final surface. The four colorized portions in the masked sample correspond to the four distinct mineral phases within the rock: Pyrite, Plagioclase, Pyroxene + Olivine, and void space (porosity).

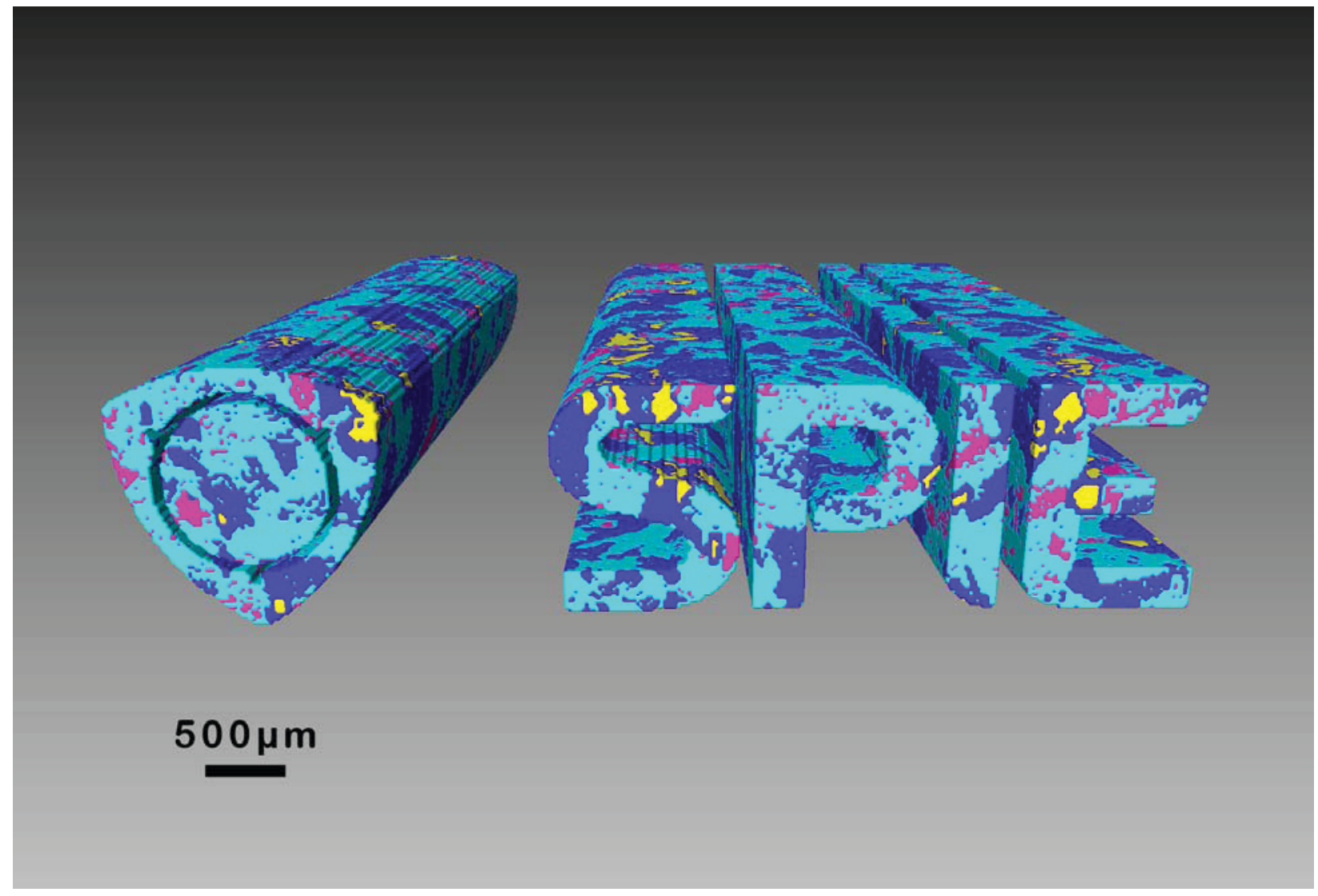




\title{
Fivefold
}

\author{
S.R. Stock* \\ ${ }^{*}$ Feinberg School of Medicine, Northwestern University, \\ Chicago, IL, USA
}

Slice showing the body plates and oral region including teeth of the sea urchin Eucidaris tribuloides. Recorded with a tube-based microCT system.

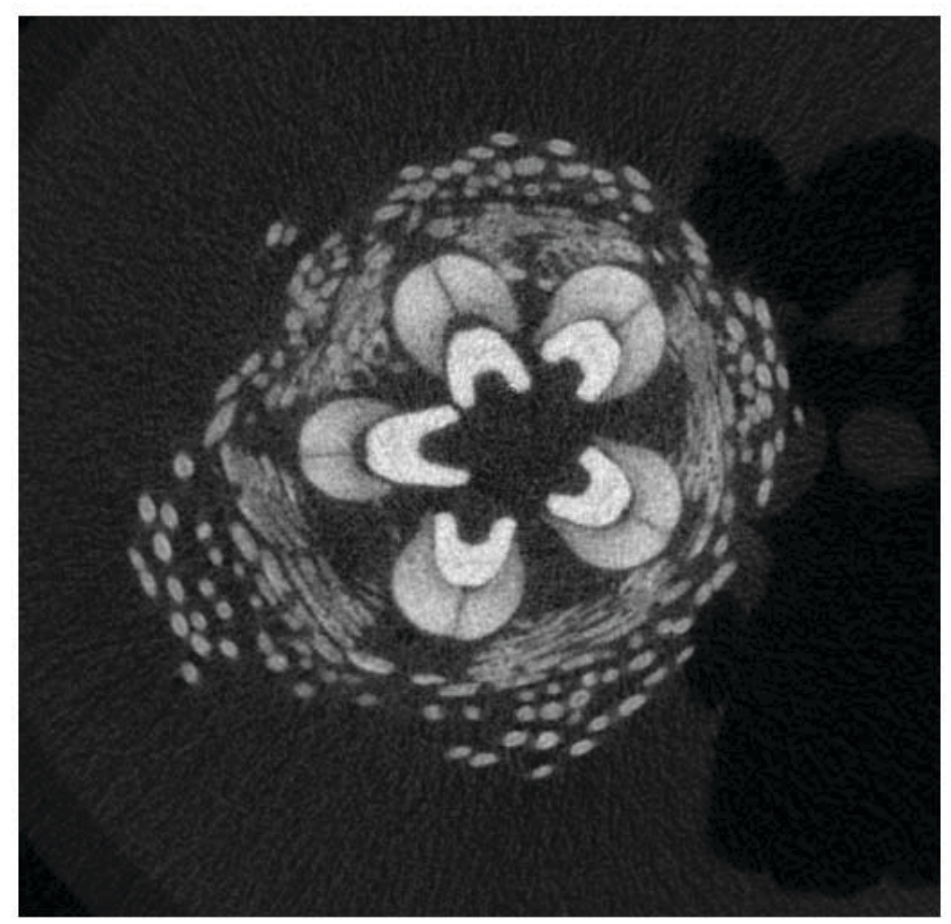




\title{
embedded
}

\author{
Sebastian Frless* and Michael Bufler \\ *Gloor Instruments AG, Switzerland
}

bone shreds embedded in a highly interconnective network of a biological matrix. scanned on a tube-based commercial highresolution microCT system

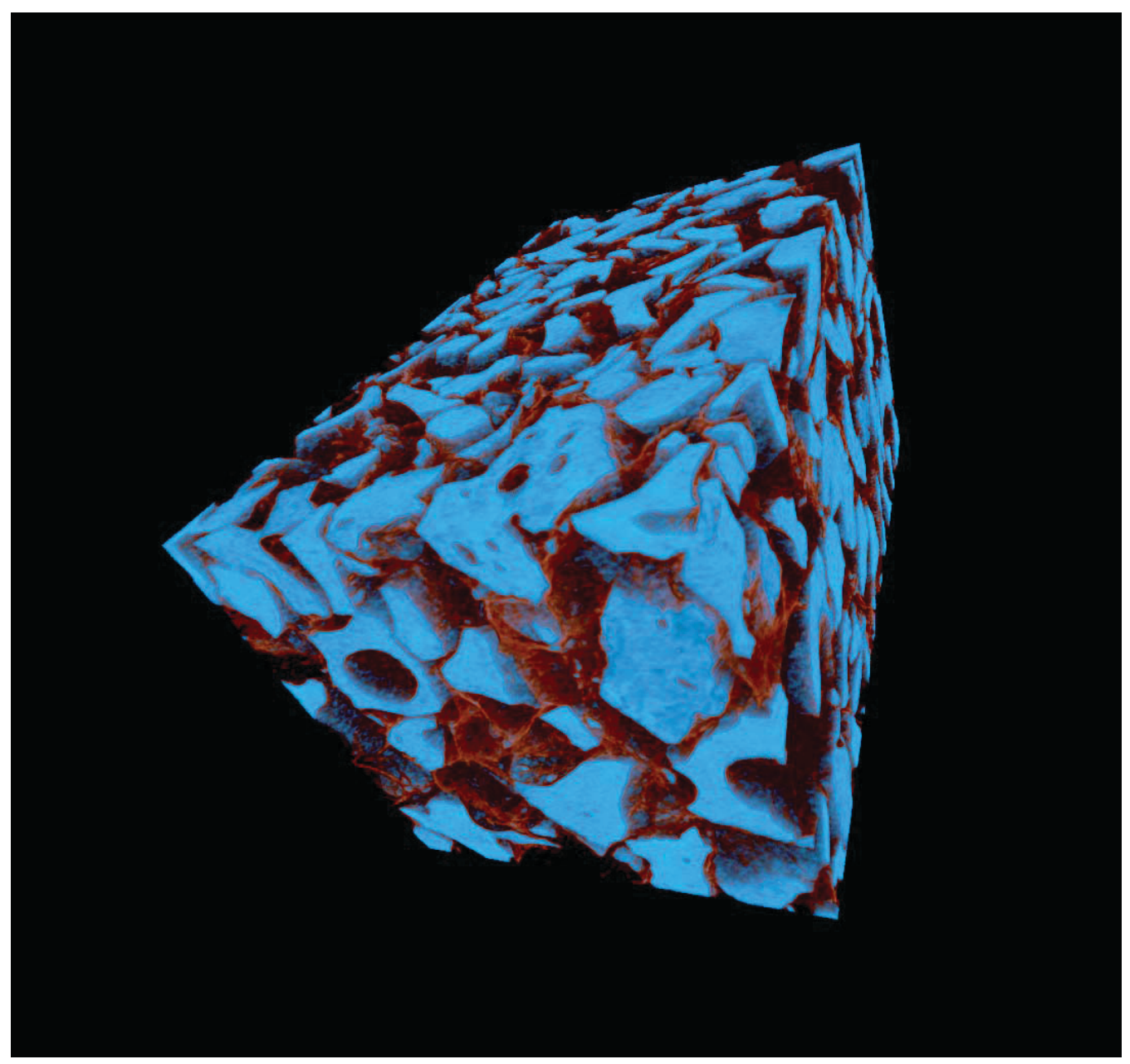




\title{
liquidus quenched
}

\author{
Mark L. Rivers \\ University of Chicago, Chicago, IL, USA
}

A piece of glass was synthesized at high-pressure and high-temperature. It was cooled below the liquidus, so crystals began to grow, and then it was quenched. The sample is about $3 \mathrm{~mm}$ in size.

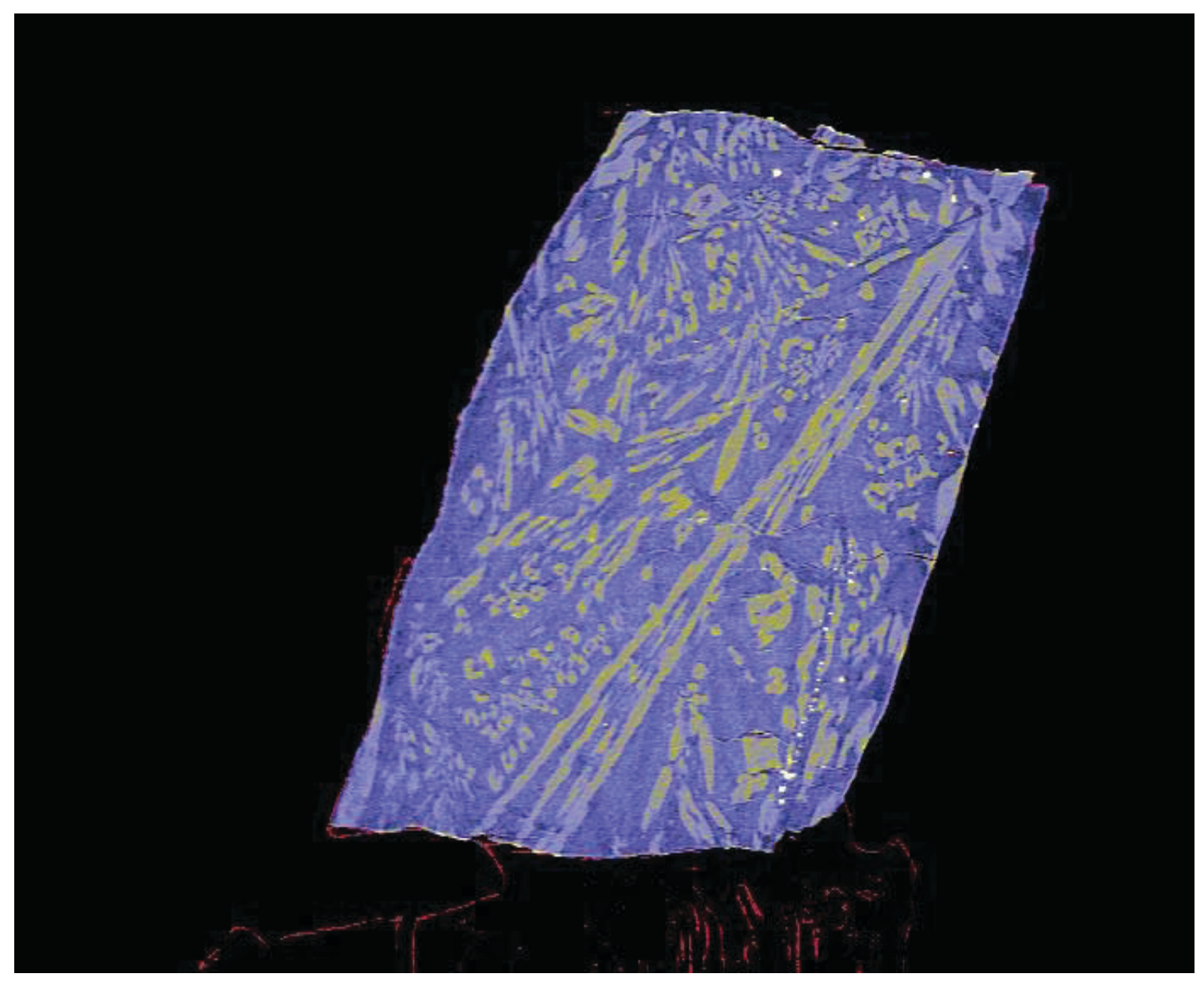




\title{
Sandstone microstructure cake
}

\author{
Sherry Mayo \& Sam Yang \\ CSIRO Materials Science \& Engineering Division \\ Private Bag 33, Clayton, Victoria 3169, Australia
}

3D view of a data-constrained modelling reconstructed

microstructure of a sandstone sample consists of quartz and calcite. The construction was based on X-ray CT images taken at 35 and $45 \mathrm{keVs}$ respectively.

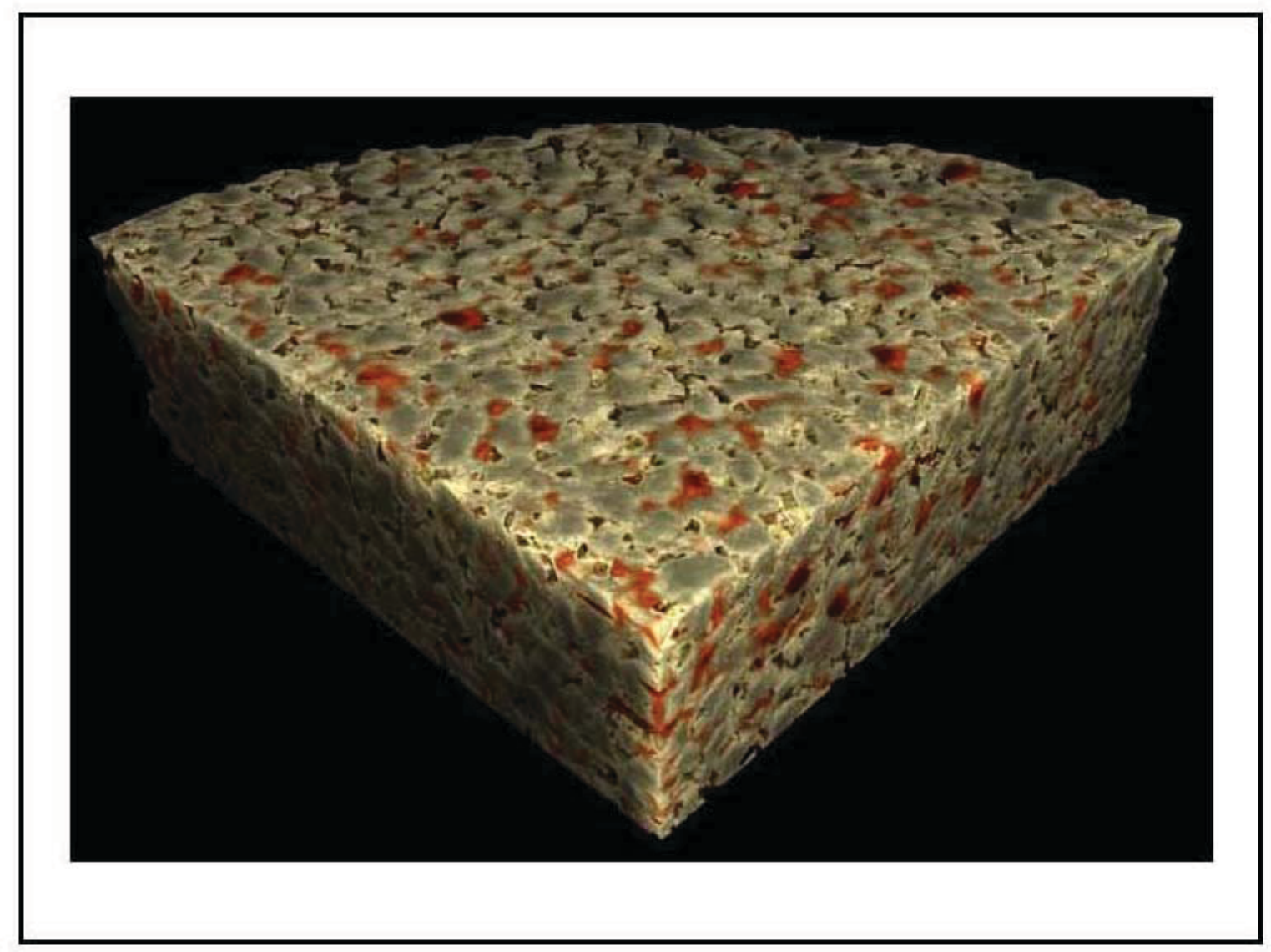


Downloaded From: https://www.spiedigitallibrary.org/conference-proceedings-of-spie on 26 Apr 2023

Terms of Use: https://www.spiedigitallibrary.org/terms-of-use 